The Internalization of Wasathiyah Values in Inclusion Madrasah: A Case Study ofIntegrated Madrasah Ibtida'iyah of Ar-Roihan Malang

Submitted: 24 December 2019, Accepted: 27 December 2019

AL-BIDAYAH: Jurnal Pendidikan Dasar Islam

ISSN: 2085-0034 (print), ISSN: 2549-3388 (online)

\title{
THE INTERNALIZATION OF WASATHIYAH VALUES IN INCLUSION MADRASAH: A CASE STUDY OF INTEGRATED MADRASAH IBTIDA'IYAH OF AR-ROIHAN MALANG
}

\author{
Sigit Priatmoko \\ Islam Darul 'Ulum Univesity Lamongan \\ E-mail: sigitpriatmoko@gmail.com
}

\begin{abstract}
The research aim is to comprehensively reveal the construction of Islamic wasathiyah values developed by Integrated Madrasah Ibtidaiyah (IMI) of Ar-Roihan and how these values are internalized into their members. This research used a qualitative approach with a case study design. The methods used to collect data are interviews, observation, and documentation. Data were analyzed using Miles and Huberman's interactive analysis model, which included four stages, namely data collection, data reduction, data presentation, and conclusions drawing. In order to obtain valid data, researchers used source triangulation techniques, triangulation methods, and extension observations. The results showed that the values of wasathiyah at IMI of Ar-Roihan were built based on the contents of the letter 'Abasa verses 1-10 and the theory of multiple intelligences. This result is by the IMI Ar-Roihan condition, which has a high plurality, which includes the characteristics and needs, intelligence, religious background of students. Based on these two main foundations and plurality, IMI of Ar-Roihan developed eight main wasathiyah values, namely equality, justice, progress, brotherhood, openness, balance, moderate, and tolerance. The eight values are internalized through three curriculum components, namely intracuricular activities, extracurricular activities, and hidden curriculum.
\end{abstract}

Keywords: Madrasah Inclusion, Wasathiyah Values, Plurality

\section{INTRODUCTION}

The radicalism concept, which is aimed at terrorism, is not a new phenomenon in Malang Raya (Malang Regency, Malang City, and Batu City), Indonesia. Some suspected terrorist arrests which occurred in few years prove that Malang has the potential to be a terrorist basecamp. As published on www.detik.com, since 2004, Malang has connected to terrorism. Muhammad Cholily or Yahya was the Dr.Azahari's bomb courier who hid Noordin M Top during his residence in Malang and was arrested 
after Antiterorism Special Detasemen 88 raided Azahari's hiding at Flamboyan Residence, Batu on July 2004. ${ }^{1}$ Further raids occurred in 2015, 2016, and 2018.

The reality cannot be ignored as such, considering that Malang is an area in which religious plurality level is relatively high. Based on the Statistical Centre Bureau (or usually called Badan Pusat Statistik/BPS) of Malang Regency in 2017, the numbers of Islam religion followers are 2,595,710 people, Protestants are 40,117 people, Chatolics are 26,612 people, Hindus are 24,507, and Buddhists are 1,869 people. ${ }^{2}$ Malang city has 709.938 Islamic people or Moslems, 52,050 Protestants, 41,779 Chatolics, 7,473 Hindus, 7,156 Buddhists, and 199 other religious followers. ${ }^{3}$ There are 209,479 Moslems, 8,351 Protestants, 2,891 Chatolics, 414 Hindus, 588 Buddhists, 5 Konghucus, and 166 people of other religions. ${ }^{4}$

Lawang Subdistrict, an area in which the research is held (Integrated Madrasah Ibtida'iyah of Ar-Roihan), is one of the subdistricts in Malang regency, which has high relative religious plurality. Based on the Report of Lawang Subdistrict in 2018, the societies of Lawang subdistrict believe in many faiths and live in harmony. Most of them are Moslems, 84,635 people. It is followed by 12,183 Christians, and 6,996 Chatolics. In line with the numbers of Moslems, the most religious facilities are mosque and surau/langgar which can be found in each village in Lawang Subdistrict. The number of mosque and langgar in Lawang Subdistrict is 93 mosques and 360 surau/langgar, and 13 Christian Churches. ${ }^{5}$

Meanwhile, in IMI of A-Roihan, plurality is also a familiar phenomenon for the societies. Integrated Madrasah Ibtida'iyah of Ar-Roihan Malang is one of the successful inclusion madrasah that becomes an example of inclusion madrasah of Religious Affairs Ministry of Republic Indonesia. This madrasah was established in 2008 under YLPI ArRoihan. In 2017, IMI of Ar-Roihan had 535 students. Since its establishment, IMI of

\footnotetext{
${ }^{1}$ Muhammad Aminudin, Cerita dan Sejarah Radikalisme di Malang, Friday $18^{\text {th }}$ May 2018https://news.detik.com/berita-jawa-timur/d-4027304/cerita-dan-sejarah-radikalisme-dimalang? ga=2.156627579.1190217851.1565164030-692442082.1542151656

${ }^{2}$ https://malangkab.bps.go.id/statictable/2016/08/10/498/penduduk-menurut-agama-dan-kecamatan2017.html

${ }^{3}$ Kota Malang dalam Angka 2016

${ }^{4}$ https://batukota.bps.go.id/statictable/2018/12/12/315/jumlah-penduduk-menurut-kecamatan-dan-agamayang-dianut-di-kota-batu-2017.html

5 Statistics Indonesia of Malang Regency, Kecamatan Lawang Dalam Angka 2018, ed. Badan Pusat Statistik Kabupaten Malang (Malang: BPS Kabupaten Malang, 2018),

https://malangkab.bps.go.id/statictable/2016/08/10/498/penduduk-menurut-agama-dan-kecamatan2017.html.
} 
Ar-Roihan has accepted children with special needs (ABK) although the teachers have not had an inclusion education background. ${ }^{6}$ As an inclusion madrasah, IMI of ArRoihan has heterogeneous students not only in academic achievement but also in other aspects such as behavior, talent, interest, and service need. Besides, the plurality in IMI of Ar-Roihan is also found in the religious background aspect. Parents of students in IMI of Ar-Roihan come from different religious society organizations, such as NU, Muhammadiyah, LDII, and so forth. ${ }^{7}$

The framework sets demands IMI of Ar-Roihan is demanded to be able to provide religious and character education which is accommodative towards plural students' lives. As long as the observation on the pre-research stage, it is found that IMI of ArRoihan has possessed hidden curriculum construction, which emphasizes on growth and development of wasathiyah character of the students. This research is aimed to explore the hidden curriculum more deeply. Therefore, how moderation or wasathiyah values are internalized into students with the plural environment is known. Defensive effort towards radicalism spread towards education is a new issue. An analysis of this effort has many been done. For example, research which was carried out by Mu'ammar Ramadhan revealed deradicalism of religion through multicultural education at the Islamic boarding house of al-Hikmah Benda Sirampog Brebes. The result indicates that multicultural education as a deradicalization effort is carried out through teaching and education, which do not stand on the certain lessons by themselves. The implementation is by using methods of habituation, discourse, discussion, demonstration, storytelling, and model. Values that are taught are kind, togetherness, and equality, respect each other, stay away from prejudice attitude towards other parties, competition in goodness, honesty, and apologize to other people.

Umi Sumbullah also performed similar research at Universitas Islam Negeri Maulana Malik Ibrahim Malang. The research indicates that UIN Maulana Malik Ibrahim Malang holds an academic and non-academic activity as a deradicalization effort. Academic activity in the form of Personality Development Courses (MPK) such as Civic Education (PKn) and character building of Ulul Albab in Ma'had. The non-

\footnotetext{
${ }^{6}$ Sigit Priatmoko, "Strategi Guru Dalam Peningkatan Mutu Pembelajaran Bagi Siswa Berkebutuhan Khusus (Studi Multisitus Di Madrasah Ibtida'iyah Terpadu Ar-Roihan Lawang Dan Sekolah Dasar Muhammadiyah 9 'Panglima Sudirman' Malang)," 2017.

${ }^{7}$ Interview with Miftachul Chotimah (Curriculum Vice Head MIT Ar-Roihan Malang), Sunday,23 ${ }^{\text {rd }}$ December 2018 at 15.00 WIB
} 
academic activity is done through students' organization building and activity programs. ${ }^{8}$ Education deradicalization, which is done so far, still focusses on students of university and students on senior high school, Islamic boarding school, and college level. While students on primary school level have not obtained an equal portion, especially on inclusion school. Whereas, primary education level is an initial foundation to build students' character. Therefore, moderate character cultivation on this level is also an important position.

\section{RESEARCH METHODS}

The approach which was utilized in this research was a qualitative approach and case study design. The data were grouped into two categories, primary and secondary data. As the method which is utilized, the primary data in this research were matters that were directly connected to the implementation of wasathiyah values internalization at IMI of Ar-Roihan. The primary data is in forms of expression of teachers, students, parents and societies concerning wasathiyah values internalization at IMI of Ar-Roihan. While the secondary data of the research were in forms of learning documents and media, photo, and many things related to wasathiyah values internalization at IMI of Ar-Roihan.

Purposive, internal and time sampling were used to determine informants. ${ }^{9}$ The sampling was based on the information depth which was obtained with the research focus. Based on purposive sampling, the researcher determined the Head of IMI of ArRoihan and Vice Head of the Curriculum Department of Madrasah as the key informants. These key informants were developed into other informants such as teachers, staff, students, and students' guardians by using snowball technique.

The data collected in this research utilized three methods, such as interviews, observation, and documentation. Meanwhile, the steps which were performed to analyze data are categorized into three stages; Collecting Data, Data Reduction, Data Display, Conclusion Drawing/Verification. In order to test the research data validation, qualitative data validity checking technique which involved credibility, transferability, dependability and confirmability test were utilized. Data credibility test will use 3

\footnotetext{
${ }^{8}$ Umi Sumbulah, "De-Radicalisation of Indonesian Students: A Case Study of UIN Malang," Pertanika Journal Social Science \& Humanities 25, no. 8 (2017): 155-164.

${ }^{9}$ Bogdan\& Biklen, Qualitative Research for Education: An introduction to theory and methods.
} 
(three) techniques, such as observation extension, data mining accuracy enhancement, and triangulation.

\section{RESULT AND DISCUSSION}

\section{Construction of Wasathiyah Values at IMI of Ar-Roihan}

The implementation of inclusion service at IMI of Ar-Roihan is based on awareness of Lailil Qomariyah that education is every individual's right. According to him, it has been clearly stated in the holy verse of the Qur'an, for example, in 'Abasa. The implication of this foundation is IMI of Ar-Roihan accepts all student candidates' tests who register, including those who have special needs. Besides, IMI of Ar-Roihan does not test candidates who register at the school. The foundation is school registration test is inappropriate because they are the candidate who is not required to study.

The test which is prevailed by IMI of Ar-Roihan to know the students' intelligence. It cannot be separated from education approach and philosophy which is applied as Multiple Intelligences. Therefore, students' talent, interest, and potential will be recognized. Besides, according to Lailil Qomariyah, the approach application is in line with Islamic teaching although Multiple Intelligences are triggered by a nonMoslem Western scientist. Besides, according to Lailil Qomariyah, if the intelligence is only merely interpreted as academic, cognitive intelligence, it is a deterioration of education. Whereas, humans have multiple intelligences which can be developed to the maximum point.

According to him, all students have each authentic disposition. Following the disposition, they can reach their achievement. In order to accommodate students' intelligences, he carried out research through observation and interview towards parents on their talent, interest, and learning style. The result becomes the handling reference which is given. The class at IMI of Ar-Roihan is based on intelligence style, which is possessed by the students. The implication which emerges from the Multiple Intelligence approach is the capability to know the students' multiple intelligences and group them into the type of intelligences. Therefore, classes at IMI of Ar-Roihan has rich diversities.

The principle of IMI of Ar-Roihan openness and inclusiveness are not only applied to accommodate physical, mental, and students' intelligence characteristics but 
also students' religious principle background. Even, it is not only a religious principle difference but also a religion difference which does not become a problem for IMI of Ar-Roihan. The same thing is also expressed by Miftachul Chotimah that various religious principles become the students' background. Students' guardians do not only follow Nahdlatul Ulama (NU) or Muhammadiyah but also Wahabi and Syiah. Although debate occurs and the school religious culture leans on NU tradition, it does not end in conflict. The difference is not only found on students' guardians but also teachers. Teachers of IMI of Ar-Roihan come from various religious principles such as NU, Muhammadiyah, Wahabi, and so forth.

According to Lailil Qomariyah, the religious principle differences between teachers and students' guardian and school religious culture cause students' confusion, especially concerning ikhtilafiyah issues. Responding to this matter, IMI of Ar-Roihan gives freedom to students. Differences which are found at IMI of Ar-Roihan is not only about principles, but also the environment of IMI of Ar-Roihan. IMI of Ar-Roihan is located beside the church and Christian school. It precisely strengthens the inclusivity of IMI of Ar-Roihan. In outline, plurality in IMI of Ar-Roihan involves three things, namely characteristics of students with a special need, students' intelligence, and religious principles. All of them have different and unique implication and need handling. It is drawn as the figure 1.

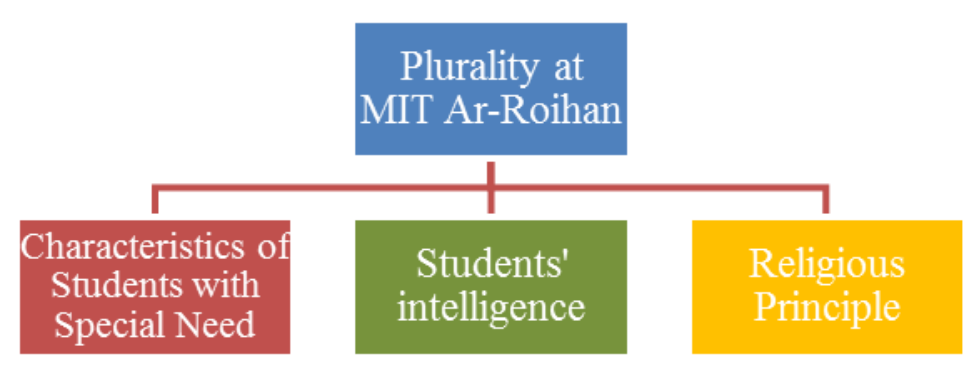

Figure 1

Plurality in IMI of Ar-Roihan

Since its beginning, the implementation of inclusive principle has made societies of IMI of MIT Ar-Roihan, from students, teachers, staff, to students' guardian to be familiarized and accustomed to the difference. Therefore, it is not an issue for them 
anymore. So, Islam wasatiyah values have been implemented and become a strength of IMI of Ar-Roihan long before wasathiyah Islam discourse is proposed lately. In outline, the construction of wasathiyah values which are developed by MIT Ar-Roihan can be presented in the Figure 2.

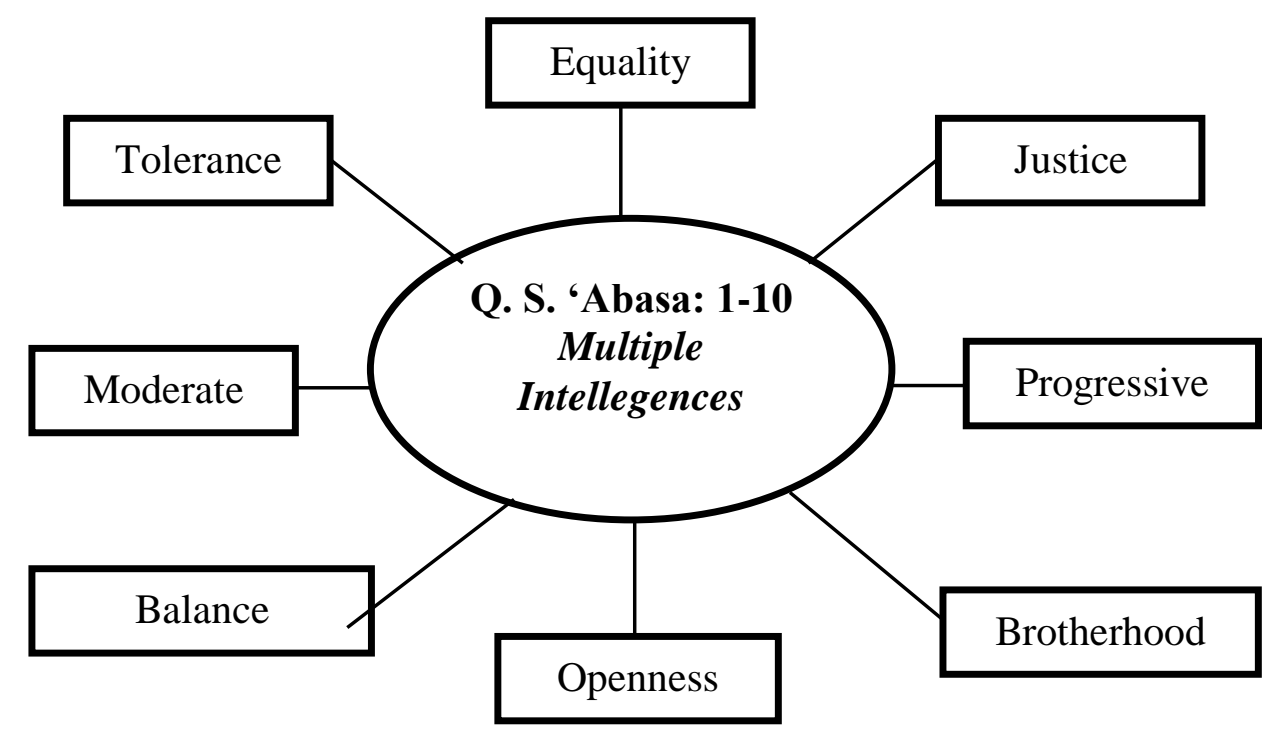

Figure 2

The Construction of Wasathiyah Values at MIT Ar-Roihan

The result of the research which was carried out by Jong Hyun Jung indicates that world societies perceive present Islam as a religion that is frightened and loses its value. In his finding, which is the analysis result of Portraits of American Life Study 2006 report data, Jung stated that 548 of 2,610 people or $21 \%$ perceive Islam as a religion that is less honored. Based on this result, at least we know that Islam is experiencing a paradox. On one side, the numbers of Islam followers show increasing graphics. However, on the other side, the Islamophobia phenomenon occurs in world societies.

The existence of discourse on moderate Islam (wasathiyah) is expected to be an antithesis of the negative stereotype. Religious affair ministry as the government institution which handles a task to carry out government matter in the religion field to help the President to state government. ${ }^{10}$ Whether or not they have a responsibility to perform mainstreaming of moderate Islamic values in order to give Islam image back.

\footnotetext{
${ }^{10}$ Religious Affair Ministry of Republic Indonesia, "Regulation of Religious Affair Minister of Republic Indonesia Number 10 Year 2010 on Organization and Working Procedure of Religious Affair Ministry" (Religious Affair Ministry of Republic Indonesia, n.d.), https://kemenag.go.id/file/dokumen/PMANo.10tahun2010.pdf.
} 
Therefore, for the last four years, the Religious Ministry affair vigorously promote Islamic moderation, including through Islam religion.

In order that Islam moderation mainstreaming in Indonesia Islam education context recently, Religious Affair Ministry through Directorate of Curriculum, Infrastructure, Institutional, and students of Madrasah formulates 12 mainstay programs, which are: (1) module organization of multiculturalism education for students of MI, MTs, and MA; (2) holding National Madrasah Scout Camp (PPMN); (3) students' strengthening towards Madrasah BERSINAR (clean, healthy, inclusive, secure, and children friendly); (4) holding an arena of Madrasah Interest and Talent in various academic or art fields; (5) socialization of multicultural education to the Head of Madrasah; (6) holding International Seminar on radicalism tackling through primary and middle education; (7) arrangement of students' assessment guideline and daily attitude and behavior development; (8) Arrangement of indication of moderation valuebased extracurricular activity; (9) The arrangement of Service Guideline in embedding rahmatan lil'alamin value for Counselor to accompany students who are prone to extremism teaching; (11) the organization of extreme teaching detection guideline in madrasah environment; (12) Socialization of deradicalization mainstreaming policy through curriculum innovation. ${ }^{11}$

According to Tarmizi Tohor, religious moderation is a moderate religious point of view, which is by understanding and applying religious teaching incompletely, whether it is right or left extreme. ${ }^{12}$ This definition is in line with the definition of wasathiyah as proposed by Yusuf Qardhawi, which is to behave in the middle and balance between two opposite aspects, in which one of aspect does not dominate all influences and erase another aspect; in which one of aspects which does not take excessive rights so that it narrows other aspect rights. ${ }^{13}$

Wasathiyah attitude has been developed by IMI of Ar-Roihan long before Religious Affair Ministry to do mainstreaming effort.

\footnotetext{
${ }^{11}$ Sauqi Futaqi, "Konstruksi Moderasi Islam (Wasathiyyah) Dalam Kurikulum Pendidikan Islam," in Proceedings of Annual Conference for Muslim Scholars, 2018, 521-530.

12 Tarmizi Tohor, "Pentingnya Moderasi Beragama," Government, Bimas Islam (blog), September 13, 2019, https://bimasislam.kemenag.go.id/post/opini/pentingnya-moderasi-beragama.

${ }^{13}$ Agus Zaenul Fitri, "Pendidikan Islam Wasathiyah: Melawan Arus Pemikiran Takfiri Di Nusantara," n.d.
} 
As stated by the head of the madrasah, the foundation of IMI establishment is equal value which is implemented on their different acceptance and appreciation attitude. It is based on the understanding of 'Abasa which tells reprimand of Allah SWT on Muhammad Prophet towards Abdullah Ibn nu Ummi Maktum. Besides 'Abasa letter, Lailil Qomariyah also makes Multiple Intelligences proposed by Howard Gardner as the institution establishment foundation. Therefore, since its establishment, IMI has become an inclusion madrasah. Even the inclusiveness which is applied by the schools is not only limited to students' physical condition but also their parents' religious background.

Based on the result of research, there are eight wasathiyah values which are constructed by IMI of Ar-Roihan. First, equality. The concept of human equality is discussed by Quran verse or hadits. For example, surah al-Hujurat verse 13; "O humankind, indeed We have created you from male and female and made you peoples and tribes that you may know one another. Indeed, the noblest of you in the sight of Allah is the most righteous of you. Indeed, Allah is knowing and Acquainted" The verse is strengthened by Prophet's words as retold by Imam Bukhori and Muslim; "Indeed Allah does not look at your appearance or possessions, but your heart and deeds."

Equality values become religious and academic culture foundation of IMI of ArRoihan. In the religious context, IMI of Ar-Roihan does not discriminate students based on their parents' religious principles background. Instead of the difference is accommodated by IMI of Ar-Roihan. Indeed the daily religious culture practice of IMI of Ar-Roihan is inclined on ahlussunnah wal jama'ah, belief of Nahdlatul Ulama (NU) perspective.

However in other religious principles such as Muhammadiyah, LDII, Persis, and so forth are accommodated. The madrasah never forces students to follow NU charitable in their daily life, however, when they are at school, they should follow madrasah religious culture. In the context of academic culture, education service which is provided for regular students or students with special needs are similar. Both types of students have same access to madrasah facility. Besides, IMI of Ar-Roihan also instills equality values into students' selves through habituation and exemplification.

Second, justice or equality. There are four justice definitions as proposed by religious experts: (1) equitable in similar meaning, (2) equality in balance meaning, (3) equitable is "attention to individuals' rights and provide them to the owner", and (4) 
equitable that is ordinated to Allah. According to Salim and Salim, justice has five definitions; (1) do not exceed or alleviate as accordingly, (2) unbiased and partial decision, (3) equal to ability, level, or position, (4) stand or hold on to propriety. (5) non-arbitrary. ${ }^{14}$

Justice value is internalized in IMI of Ar-Roihan through daily interaction by habituating and giving an example. Habituation to behave equally is done through simple daily activities. For example, do not litter, do not rowdy when studying, indiscriminative towards friends, end so forth. While the exemplification is done through education service delivery which is based on the justice principle, teachers' indiscriminative attitudes towards students, providing decisions towards impartial religious conflict, and so forth.

Third, progressive. In the typology, Khaled Abou El Fadl reveals the definition of moderate Muslims as people who believe in Islam as the right belief and practice and believe in the five pillars of Islam, accept Islamic tradition inheritance, and modify certain aspects of it. They position Islam as a frozen monument, and vice versa, place it on dynamic and active belief perception. As a consequence, they respect past achievement, but they are aware that they live in the present. ${ }^{15}$ Considering El Fadl's definition, it indicates that moderate Muslims (wasathan) are progressive Muslims. They dialectically perceive holy texts (nash-nash) as the source of Islam teaching. As a consequence, the teaching is not understood as principles which are born from ahistorical space and separated from contextual reality. On the contrary, they are result of revelation struggle with contextual reality from time to time which is bound by space and time.

If it is connected to IMI of Ar-Roihan context, this progressive value in possession is "Creating Qur'ani Global Generation." According to Lailil Qomariyah, the word "Global" indicates IMI of Ar-Roihan willpower to create graduates who have global insight and are ready to be the world people. Besides the vision, IMI of ArRoihan progressiveness is also seen from the classroom naming, which are Middle East cities which are Islam civilization cities. It is done to familiarize and explain students on

\footnotetext{
${ }^{14}$ Nurdin Nurdin, "Konsep Keadilan Dan Kedaulatan Dalam Perspektif Islam Dan Barat," Media Syari'ah 13, no. 1 (2017): 121-130.

${ }^{15}$ Ahmad Dimyati, "Islam Wasatiyah," Islamic Review: Jurnal Riset Dan Kajian Keislaman 6, no. 2 (2017): 139-168.
} 
Islam civilization greatness and become societies' education effort. Extra efforts which are done to internalize progressive values towards students are students' participation in the national or international contest. IMI of Ar-Roihan students often obtains the championship of those contests. IMI of Ar-Roihan curriculum also indicates that it always tries to be the forefront. When other schools are confused with the implementation of Curriculum 2013, IMI of Ar-Roihan is on the forefront to apply it.

The effort done by IMI of Ar-Roihan is in harmony with one of wasathiyah Islam characteristics of Yusuf Qardhawi, which is uniting the past inheritance, present reality and future magnificence. In Nahdlatul Ulama (NU), it is known as genealogy "almuhafadzatu ala qadimissholih wal akhdu bil jadidil ashlah" which is defined as "maintaining good past and take a better new one." It indicates that NU as Islam religious society organization wants them to support development. As El-Fadl's opinion that moderate Muslims are they who do not treat religion as frozen monument, but in dynamic and active faith framework. (ukhuwah). In Islam, three known brotherhood forms are ukhuwah Islamiyah, ukhuwah wathaniyah, and ukhuwah basyariyah. The three brotherhood typologies are many discussed in holy texts. The three typologies become Muslims in their interaction. Through ukhuwah concept, Muslims are united into one vision. As said by Allah in Surah Al-Hujurat verse 10; "The believers are but brothers, so make settlement between your brothers. And fear Allah that you may receive mercy." Through brotherhood which is based on this belief unity, Muslims are called to strengthen unity and coalescence.

Prophets also draw the close relationship between a Muslim to another, such as body part to another. If one of the body parts is injured, the other feels the pain. The parable signals a close relationships among Muslims. Therefore Muslim conflict can be said as apostolic hurt will. ${ }^{16}$ The internalization of $u k h u w a h$ value at MIT Ar-Roihan is manifested in mutual help attitude habituation among students without differentiating who is helped. Students are not only taught the brotherhood concept, which is integrated into one lesson but also experience it directly through daily activities. For example, regular students help students with a special need who are experiencing difficulty, giving support to friends who are joining a contest, and mutual share.

\footnotetext{
${ }^{16}$ Ikhwan Hadiyyin, "Konsep Pendidikan Ukhuwah: Analisa Ayat-Ayat Ukhuwah Dalam Al-Qur'an,” Al Qalam 33, no. 2 (2016): 26-51.
} 
Fourth, openness. IMI of Ar-Roihan acceptance on students' diversity in physical, psychological, and religious principles of their parents until the present is the proof that this institution is consistency with their foundamental principle. So, since the beginning students of IMI of Ar-Roihan have been accustomed to the inclusive environment. It affects students' attitude which will be faced on plurality which covers their world. The ability to be open makes an individual be uneasy in accusing or hostile towards people who are different from them.

Openness is one of the moderate Muslim characteristics (wasathiyah). As stated by Yusuf Qardhawi, who is performing bil hikmah missionary endeavor, and willing to have a dialogue with other parties who set out ethics. Willingness to have a dialogue with other different parties that set out ethics will never be implemented without an individual' openness attitude. In more global and multicultural reality and association, openness attitude is required by an individual to show the existence and actualize him/herself. Without the attitude, he/she will find difficulty in the participation of global conflict. He/she will be alienated and marginalized because of exclusiveness.

Exclusive attitude as the antithesis of inclusive attitude has been the cause of fundamentalism principles in religion. Khaled Abou El-Fadl mentions this group as puritan people who are the opposites of moderate Muslims. The distinction of moderatepuritan is seen on how they act towards non-Muslim related to religion, salvation and plurality. According to El-Fadl, puritan people assume that the only community that deserves to get salvation is the Muslims community, not non-Muslims. This concept is based on surah Ali Imran verse 19 and 85. In verse, the word "Islam" is rigidly translated into a religion, which is brought by Muhammad SAW prophet. Besides, Islam people or Muslim who do not practice their religious teaching as their interpretation do not have salvation rights. ${ }^{17}$ The absence of openness attitude becomes the root of socialreligious conflict that mushrooms for some recent decades.

Sixth, balance. IMI of Ar-Roihan, in their religious culture applies NU principles, which one of them is balance or tawazun. This principle has balance meaning in every case, including the use of 'aqli theorem (theorem which is sourced from rational thinking meaning) and naqli theorem (which is sourced from Al-Qur'an and Hadits).

\footnotetext{
${ }^{17}$ Djami'atul Islamiyah, "Realitas Pemikiran Islam: Moderat-Puritan," Millati: Journal of Islamic Studies and Humanities 2, no. 2 (December 15, 2017): 145, https://doi.org/10.18326/mlt.v2i2.145-168.
} 
Therefore, IMI of Ar-Roihan does not only focus on developing students' religious attitudes but their intellectual competence. Besides, in amaliyah practice, IMI of Ar-Roihan as NU tradition does not only base on naqli theorems in forms of alQur'an and Hadits, but also aqli that is manifested through logic use in science development.

As said by Yusuf Qardhawi, one of moderate characteristics are maintaining balance between syara' determination and contemporary. The implementation of balance value at IMI of Ar-Rahman can also be seen from religious culture and vision and mission. The vision of IMI of Ar-Roiihan is "Creating Qur'ani Global Generation". The word use "Global" which is paired up with "Qur'ani" indicates that not only religious charitable which is developed at IMI of Ar-Roihan but also global insight that will be a future provision for students.

Seventh, moderate. Background of students' parents' religious principles is different (NU, Muhammadiyah, LDII). Small frictions occur for a few times, especially if it is related to prayer rite. IMI of Ar-Roihan was established by NU care, so the religious culture which is developed is affiliated with NU. Some parents do not permit their children to join school religious activities because they assumed as not in line with their principle.

Ar-Roihan acts strictly in order to respond to this matter. As informed by Lailil Qomariyah, since the initial registration, madrasah has clearly and explicitly explained that religious culture at IMI of Ar-Roihan is based on ahlusunnah wal jamaah NU principles. Madrasah provides freedom to students' guardian to continue the registration or not. It is done through an open house program which is held on each New Student Recuitment. Besides, IMI of Ar-Roihan does not force their students to follow NU charitable as each student parents' guidance. Therefore, it is determined that all students without discriminating whether they are NU, LDII, and Muhammadiyah.

This fair policy (moderate) indirectly becomes learning for students related to how to face the environment, which is eventful with diversity. It is important because through a moderate attitude, attitude will grow within the students' selves. This attitude enables students to interact with many people from various backgrounds. This moderate attitude will border students from radicalism. As we have known, one of the radicalism causes is the cultural factor, which is closely related to shallow and neglectful religious 
understanding towards contextual reality. ${ }^{18}$ Moderat attitude will become an urgent thing in the more widespread personal interest, group, and class conflict. The moderate attitude becomes an vital capital to take reconsiliation step because it is able to accommodate various existing interests and find a win-win solution. ${ }^{19}$

Eighth, tolerance. Tolerance or in Arabic is called tassammuh based on Yusuf Qardhawi perception ${ }^{20}$ is one of wasathiyah Islam characteristics. According to him, a moderate Muslim should; (1) focus on objective and tolerant in determining the facilities to reach it. (2) run bil hikmah missionary endeavor and be willing to have dialogue wth other parties that set out ethics, (3) reconsiliation towards faithful leaders who are tolerant with parties that have different perceptions. Tolerance in IMI of ArRoihan refers to the first characteristic, a place in multiple intelligences-based learning approach whichis applied since its establishment. This approach enables the management of students' potentials as their intelligence.

While on the second characteristic, it is seen in IMI of Ar-Roihan effort to build cooperation with Christian schools and institutions around them. IMI of Ar-Roihan is not reluctant to participate and invite the schools and institutions, although they have different religion. In daily practice, bil hikmah missionary endeavor and dialog which promotes ethics, is also seen in teachers' efforts to attune the students to be tolerant with different friends. Whether it is physical or mental characteristics. The last characteristic is seen when friction between students' guardians and teachers concerning worship amalaiyah program at school and lesson, especially religion lesson. Madrasah party performs the audience through WhatsApp (WA) groups of students' guardian community that is managed by each homeroom teacher.

\section{Strategy of Wasathiyah Values Internalization at IMI of Ar-Roihan}

\section{Intraculicular Activities}

The strategy of wasathiyah values internalization at MIT Ar-Roihan is done through intracurricular activity in form of integration into lesson. Wasathiyah values such as equality, openness, tolerance, justice, balance, justice, development, etc are not

\footnotetext{
${ }^{18}$ National Agency for Combating Terorism, "Strategi Menghadapi Paham Radikalisme TerorismeISIS," Jakarta: Belmawa, 2016.

${ }^{19}$ Ngainun Naim, "Pengembangan Pendidikan Aswaja Sebagai Strategi Deradikalisasi," Walisongo: Jurnal Penelitian Sosial Keagamaan 23, no. 1 (2015): 69-88.

${ }^{20}$ Dimyati, "ISLAM WASATIYAH."
} 
discussed as the subject but integrated into all lessons. Particularly, cluster of socialhumanities and Islam Education subject, such as Citizenship Education, Social Science, Moral Theology, al-Qur'an Hadist, etc. Principles which cannot be ignored in value internalization process is sustainable. It means that the internalization process is done gradually and continuously.

The next principle that should be considered is the value is developed. Lesson material which is done as media to develop cultural values and the nation's character, and education process are performed by students actively and fun. Character education pillars of character/value development micro can be divided into four pillars, which are classroom learning, daily activity in the form of school culture, co-curricular and/or extracurricular activity, and daily activity at home and societies. ${ }^{21}$

Intracurricular activity or learning activity in value education has strategic roles. Besides, it is the core of education activity at school, intracurricular activity also provides the opportunity of the transmission process and knowledge construction. As stated by Superka that among strategies that value internalization applied at school are (1) inculcation approach, (2) cognitive moral development approach, (3) value analysis approach, (4) values clarification approach, and (5) action learning approach. ${ }^{22}$ These five approaches can be carried out through intracurricular activity. On the inculcation approach, IMI of Ar-Roihan, through teachers do not forget to give reinforcement towards students. Positive reinforcement in forms of praise, appreciation, gift, or involvement of students in classroom activity which is given if students can actualize values which are developed, including wasathiyah values such as tolerance, brotherhood, development, etc. While negative reinforcement in the form of sanction or law when students indicate negative behavior of in the opposite of values which are developed. For example, students bully friends with special needs, fight, are noisy in the classroom or violate other rules.

Besides the reinforcement method, IMI of Ar-Roihan in implementing the inculcation approach also uses exemplary method or modeling. For example, in embedding tolerance value, teachers do not only teach their concept in the classroom

\footnotetext{
${ }^{21}$ Prawidya Lestari, "Membangun Karakter Siswa Melalui Kegiatan Intrakurikuler, Ekstrakurikuler, Dan Hidden Curriculum Di SD Budi Mulia Dua Pandeansari Yogyakarta," Jurnal Penelitian 10, no. 1 (2016): 71-96.

${ }^{22}$ Douglas P. Superka, "Values Education Sourcebook: Conceptual Approaches, Materials Analyses, and an Annotated Bibliography." 1976.
} 
but also give a real example through daily activity. Modeling is an effective method in instilling value. The learning process of primary school age children in Jean Piaget's development theory is in imitating stage. Therefore, the implementation of modelling method is the right step. As stated by Muhammad Qutb, modeling method is the most effective and efficient method to reach education success. ${ }^{23}$ The imitation process is initiated with an aware. As we have known, teachers' positions within the children's self as parents. Even in some cases, teachers are idolized by children. The awe feeling will gradually encourage students to follow and imitate the behavior of the person they adore. $^{24}$ This imitation process is followed with reinforcement, so students' motivation to behave positively as modelled by teachers will increase. Therefore, values which are developed (wasathiyah values) can be instilled firmly within the children.

The next approach that can also be applied in intracurricular is values clarification approach. The term value clarification as a learning process model was firstly used by Louis Raths in 1950s when he taught at New York University. The mode of VCT learning is "teaching technique to help students finding and determining good value in facing problems through value analysis that has been possessed by students." In other words, this approach tries to instill values through clarification steps which are done by the students themselves. The unique characteristics of VCT learning model is the implementation of values on students by harmonizing values which are possessed by them and new values that will be applied that by Darmiyati Zuchdi (2008) is called as "value observation process". This harmonization will protect value stability as the base of students' characters in more complex value understanding change because it is found by themselves through rational process. ${ }^{25}$

\section{Extracurricular Activity}

Extracurricular activity is one of education aspects that obtain serious attention from IMI of Ar-Roihan. There are 30 (thirty) extracurricular types which are provided to students. The numbers are based on students' talent, interest, and type of intelligence. As previously stated, education approach at IMI of Ar-Roihan uses multiple

\footnotetext{
${ }^{23}$ Rahendra Maya, "Pemikiran Pendidikan Muhammad Quthb Tentang Metode Keteladanan (Al-Tarbiyah Bi Al-Qudwah)," Edukasi Islami: Jurnal Pendidikan Islam 6, no. 11 (2017): 16.

${ }^{24}$ Hafsah Sitompul, "Metode Keteladanan Dan Pembiasaan Dalam Penanaman Nilai-Nilai Dan Pembentukan Sikap Pada Anak," Darul Ilmi 4, no. 1 (2016).

${ }^{25}$ Nunuk Suryani, "VCT (Value Clarification Technique) Learning Model Application to Improve Historical Value Understanding," Historia: Jurnal Pendidik Dan Peneliti Sejarah 11, no. 2 (2010): 198217.
} 
intelligences paradigm which is developed by Howard Gardner. The approach implementation enables IMI of Ar-Roihan to accommodate students' self actualization with the intelligence they possess.

According to Anifral Hendri, ectracurricular activities have four functions; ${ }^{26}$ first, development. Through the extracurricular activity, the school can develop students' abilities and creativity as the interest, talents, and potential of the students. Second, social. Extracurricular can be media for students to develop their ability and social responsibility. Third, recreative. Since students join the extracurricular happily, they are able to find happiness and refreshing from the saturation of learning in classroom. Students of extracurricular members often achieve championship. They achieve regional or national championship. It occurs because they feel happy and free in studying. Fourth, career preparation. Through extracurricular, students' potential, talent, and interest are sharpened to develop and become additional skill provisions for them in the future.

Considering National Education System, Act No 20 of 2003 that the function of national education is to develop students' potential as written in the article 3 . Article 4 paragraph (4) mentions that education is carried out by giving example, build willingness and develop students' creativity in the learning process. Article 12 Paragraph (1b) mentions that each student on each education unit deserves to get education service as the talent, interest and ability. ${ }^{27}$

Extracurricular activity in IMI of Ar-Roihan is not only utilized as medium to develop potential, creativity, and knowledge of students as their talent and interest. Moreover, extracurricular is also utilized as a medium to instill wasathiyah values, such as brotherhood value, openness, tolerance, progressive, or development etc. On scout extracurricular, besides developing intelligence, creativity, and skill, this extracurricular still instills brotherhood values, tolerance, nationalism, tenacity, etc which are integrated into every activity. If it is paired up with education approach such as Superka value, it can be said that the implementation of extracurricular is the form of action learning

\footnotetext{
${ }^{26}$ Lestari, "Membangun Karakter Siswa Melalui Kegiatan Intrakurikuler, Ekstrakurikuler, Dan Hidden Curriculum Di SD Budi Mulia Dua Pandeansari Yogyakarta."

${ }^{27}$ Republik Indonesia, "Undang-Undang Republik Indonesia Nomor 20 Tahun 2003 Tentang Sistem Pendidikan Nasional," Jakarta: Pemerintah Republik Indonesia, 2003.
} 
approach, in which students are directly involved and experience how values are reversed into real activity.

\section{Hidden Curriculum}

This third strategy can be said as a strategy that has the most significant effect compared with two previous strategies. As said by resource, the internalization process of wasathiyah values at IMI of Ar-Roihan is done through the hidden curriculum. It means, it does not stand alone as a subject or other curriculum activity. However, wasathiyah values are instilled into the students' selves through habituation and modeling from teachers which is framed in religious and academic culture and daily interaction. The examples are flag ceremony and kultum or discourse uses. As explained previously, the mandate of the flag ceremony and kultum coach is about five mottos of IMI of Ar-Roihan, such as Tawheed, Quranic, Scholar, Independent and Care. It is done continuously and repeatedly, so wasathiyah values which are found in the motto will unconsiously be embedded in students.

The habituation process is done through madrasah regulations. For example, bullying prohibition to students with special needs. Students who break this rule will bear a light, moderate to severe sanction. Programs of praying Dhuha in congregation, istighotsah, celebration of Islam religious day (PHBI), social devotion, communal work to clean classroom, etch are examples of habituation in order to embed wasathiyah values. Through this activity, students are unconsciously studying and embedding noble values such as brotherhood, tolerance, openness, justice, balance etc. This habituation process is supported by modelling from teachers. Madrasah party emphasizes on discipline and integrity of teachers. The education service of IMI of Ar-Roihan as stated by Lailil Qomariyah is customer oriented which is in this context is the student. Both madrasah and teachers are required to provide education as good as possible.

If we look at it, wasathiyah values internalization at IMI of Ar-Roihan through hidden curriculum is unvarying with Action Learning Approach as proposed Douglas Superka. This research excellence is able to provide special opportunity for students to act based on values they possessed. Many teaching methods which are utilized in analysis approach and clarification are also applied in this approach. However, both unique techniques for action approach is skill practice in group organization and 
interpersonal relationship and action project, which provide the opportunity to be involved in individual or group action at school and society.

Seddon T. in his book "The Hidden Curriculum an Overview: Curriculum Perspectives", states that hidden curriculum refers to education results and/or process which directs to the result that is inexplicitly intended by the teachers. This result is intended explicitly because it is not stated by teachers in oral or written objectives list, not included in the statement of educational objectives such as syllabus, school policy document, or curriculum project. ${ }^{28}$

\section{CONCLUSION}

One of the efforts to handle the widespread phenomenon on fundamentalism, radicalism, and terrorism is through religious moderation mainstreaming or in Islam it is called as wasathiyah. As inclusion madrasah, IMI of Ar-Roihan since its establishment has tried to internalized wasathiyah values in their students. These values are constructed from an awareness that humans have equal positions and rights to obtain education. This awareness is imbued by Surah 'Abasa verse 1-10 and multi intelligences theory which is proposed by Howard Hardner. Of two grand theories, IMI of Ar-Roihan develops eight values: equality, justice, progressive, brotherhood, openness, balance, moderate and tolerance.

The eight values are internalized by using approach which by Douglas Superka is called as (1) inculcation approach, (2) cognitive moral development approach, (3) values analysis approach, (4) values clarification approach, and (5) action learning approach. These five approaches are not explicitly and rigidly applied, but is framed into three strategies which are curriculum components, which are intracurricular, extracurricular and hidden curriculum.

\footnotetext{
${ }^{28}$ Lestari, "Membangun Karakter Siswa Melalui Kegiatan Intrakurikuler, Ekstrakurikuler, Dan Hidden Curriculum Di SD Budi Mulia Dua Pandeansari Yogyakarta."
} 


\section{REFERENCES}

Badan Pusat Statistik Kabupaten Malang. Kecamatan Lawang Dalam Angka 2018. Edited by Badan Pusat Statistik Kabupaten Malang. Malang: BPS Kabupaten Malang, 2018.

Dimyati, Ahmad. "Islam Wasatiyah." Islamic Review: Jurnal Riset Dan Kajian Keislaman 6, no. 2 (2017): 139-168.

Futaqi, Sauqi. "Konstruksi Moderasi Islam (Wasathiyyah) Dalam Kurikulum Pendidikan Islam." In Proceedings of Annual Conference for Muslim Scholars, 521-530, 2018.

Hadiyyin, Ikhwan. "Konsep Pendidikan Ukhuwah: Analisa Ayat-Ayat Ukhuwah Dalam Al-Qur'an.” Al Qalam 33, no. 2 (2016): 26-51.

Presiden of Republic Indonesia. (2003). "Law of the Republic of Indonesia Number 20 of 2003 concerning the National Education System." Jakarta: Government of the Republic of Indonesia, 2003.

Islamiyah, Djami'atul. "Realitas Pemikiran Islam: Moderat-Puritan." Millati: Journal of Islamic Studies and Humanities 2, no. 2 (December 15, 2017): 145. https://doi.org/10.18326/mlt.v2i2.145-168.

Jung, Jong Hyun. "Islamophobia? Religion, Contact with Muslims, and the Respect for Islam." Review of Religious Research 54, no. 1 (March 1, 2012): 113-26. https://doi.org/10.1007/s13644-011-0033-2.

Ministry of Religious Affairs of Republic Indonesia. "Regulation of the Minister of Religion of the Republic of Indonesia Number 10 of 2010 concerning the Organization and Work Procedure of the Ministry of Religion", 2010. https://kemenag.go.id/file/dokumen/PMANo.10tahun2010.pdf.

Lestari, Prawidya. "Membangun Karakter Siswa Melalui Kegiatan Intrakurikuler, Ekstrakurikuler, Dan Hidden Curriculum Di SD Budi Mulia Dua Pandeansari Yogyakarta." Jurnal Penelitian 10, no. 1 (2016): 71-96.

Maya, Rahendra. "Pemikiran Pendidikan Muhammad Quthb Tentang Metode Keteladanan (Al-Tarbiyah Bi Al-Qudwah).” Edukasi Islami: Jurnal Pendidikan Islam 6, no. 11 (2017): 16.

Muzayanah, Umi. "Penyelenggaraan Pendidikan Inklusif Pada Madrasah Ibtidaiyah (MI) Keji Ungaran Jawa Tengah.” Penamas 29, no. 2 (2016): 121-226.

Naim, Ngainun. "Pengembangan Pendidikan Aswaja Sebagai Strategi Deradikalisasi." Walisongo: Jurnal Penelitian Sosial Keagamaan 23, no. 1 (2015): 69-88.

Nurdin, Nurdin. "Konsep Keadilan Dan Kedaulatan Dalam Perspektif Islam Dan Barat." Media Syari'ah 13, no. 1 (2017): 121-130. 
Priatmoko, Sigit. "Strategi Guru Dalam Peningkatan Mutu Pembelajaran Bagi Siswa Berkebutuhan Khusus (Studi Multisitus Di Madrasah Ibtida'iyah Terpadu ArRoihan Lawang Dan Sekolah Dasar Muhammadiyah 9 'Panglima Sudirman' Malang)," 2017.

Ramadhan, Muammar. "Deradikalisasi Agama Melalui Pendidikan Multikultural Dan Inklusivisme (Studi Pada Pesantren al-Hikmah Benda Sirampog Brebes)." Jurnal SMART (Studi Masyarakat, Religi, Dan Tradisi) 1, no. 2 (2015).

Rusli, Rusli. "Gagasan Khaled Abu Fadl Tentang "Islam Moderat Versus Islam Puritan (Perspektif Sosiologi Pengetahuan).” Jurnal Ilmiah Ilmu Ushuluddin 8, no. 1 (January 4, 2009): 99. https://doi.org/10.18592/jiiu.v8i1.1371.

Sitompul, Hafsah. "Metode Keteladanan Dan Pembiasaan Dalam Penanaman NilaiNilai Dan Pembentukan Sikap Pada Anak.” Darul Ilmi 4, no. 1 (2016).

Sumbulah, Umi. "De-Radicalisation of Indonesian Students: A Case Study of UIN Malang." Pertanika Journal Social Science \& Humanities 25, no. 8 (2017): $155-164$.

Superka, Douglas P. "Values Education Sourcebook: Conceptual Approaches, Materials Analyses, and an Annotated Bibliography.," 1976.

Suryani, Nunuk. "VCT (Value Clarification Technique) Learning Model Application to Improve Historical Value Understanding." Historia: Jurnal Pendidik Dan Peneliti Sejarah 11, no. 2 (2010): 198-217.

Terorisme, Badan Nasional Penanggulangan. "Strategi Menghadapi Paham Radikalisme Terorisme-ISIS.” Jakarta: Belmawa, 2016.

Tohor, Tarmizi. "Pentingnya Moderasi Beragama." Government. Bimas Islam (blog), September 13, 2019. https://bimasislam.kemenag.go.id/post/opini/pentingnyamoderasi-beragama.

Zaenul Fitri, Agus. "Pendidikan Islam Wasathiyah: Melawan Arus Pemikiran Takfiri Di Nusantara," n.d. 